\title{
Analisis Sentimen Masyarakat Terhadap Pilpres 2019 Berdasarkan Opini Dari Twitter Menggunakan Metode Naive Bayes Classifier
}

\author{
Khoirul Zuhri ${ }^{1}$, Nurul Adha Oktarini Saputri ${ }^{2}$ \\ ${ }_{1}^{1}$ Information System Departement, Bina Darma University, Palembang, Indonesia \\ 2Informatics Departement, Bina Darma University, Palembang, Indonesia \\ Email: 1khoirulzuhri014@gmail.com,2nuruladhaos@binadarma.ac.id
}

\begin{abstract}
Twitter is a social media that is currently popular, where the public is free to comment and write anything. It is not uncommon for the public to comment with harsh words and even hate speech. The 2019 presidential election drew many comments, some praised, criticized and insulted. To be able to dig up information and classify a text, sentiment analysis is needed. In this study, sentiment analysis is a process of classifying textual documents into two classes, namely negative and positive sentiment classes. Opinion data were obtained from the Twitter social network in the form of tweets. The data used was 3337 tweets consisting of $80 \%$ training data and $20 \%$ training data. Training data is data with known sentiment. This study aims to determine whether a tweet is a positive or negative tweet conveyed on Twitter in Indonesian. The classification of tweet data uses the naïve Bayes classifier algorithm. The classification results of the test data show that the Naïve Bayes Classifier algorithm provides an accuracy value of $71 \%$. The accuracy value for each sentiment is $71 \%$ for positive sentiment and $70 \%$ for negative sentiment.
\end{abstract}

Keywords: Sentiment Analysis, Classification, Naïve Bayes, Twitter, Pilpres 2019

\section{PENDAHULUAN}

Seiring dengan semakin majunya teknologi telekomunikasi, pengguna internet di dunia juga mengalami kemajuan yang cukup pesat. Hal ini dikarenakan semakin mudahnya aktifitas sehari-hari yang bisa dilakukan dengan memanfaatkan internet, baik itu hanya sekedar berkomunikasi melalui media sosial, mencari informasi secara up to date dan bahkan melakukan transaksi jual beli. Menurut data dari Internet World Status, Indonesia merupakan salah satu Negara dengan pengguna internet 
Vol. 1, No. 3, September 2020 e-ISSN: 2775-2496

https://journal-computing.org/index.php/journal-cisa/index

terbesar di Dunia yang menempati posisi ke-5 dengan 143.260.000 pengguna. Perilaku pengguna internet lebih didominasi untuk mengakses media sosial seperti Facebook, Twitter, Instagram, YouTube sebesar $97,4 \%$ dari total pengguna internet.

Media sosial didefinisikan sebagai alat (tools) tekno logi informasi online yang memungkinkan setiap pengguna melakukan komunikasi dengan mudah melalui internet dalam berbagi informasi seperti pesan teks, audio, video, gambar dan lain sebagainya [1]. Media sosial saat ini bukan hanya dipergunakan untuk sarana pertemanan saja, tapi sudah banyak untuk kegiatan lain, seperti pengenalan suatu produk ataupun untuk sarana masyarakat dalam mengomentari hasil pilpres 2019.

Pemilihan Presiden 2019 sudah selesai dilakukan, dan banyak menghasilkan bermacam-macam opini dari masyarakat terutama melalui media sosial Twitter. Opini melalui tweet inilah yang dapat dimanfaatkan untuk melihat bagaimana sentimen yang dimunculkan oleh masyarakat mengenai Pilpres 2019. Penentuan sentimen positif, negatif sebenarnya bisa dilakukan secara manual, tetapi karena data yang sangat banyak maka menjadi semakin bayak tentunya waktu dan usaha yang dibutuhkan untuk mengklasifikasikan opini-opini tersebut. Oleh sebab itu peneliti tertarik dalam menerapkan motode pembelajaran mesin untuk mengklasifikasikan opini dari data yang sangat banyak tersebut. Untuk melakukan klasifikasi data tersebut peneliti menggunakan metode Naive Bayes Classifier.

Metode Naive Bayes Classifier merupakan salah satu metode machine learning yang menggunakan perhitungan probabilitas. "Cara kerja dari metode Naive Bayes Classifier menggunakan per hitungan probabilitas". Konsep dasar yang digunakan oleh Naive bayes adalah Theorema Bayes, yaitu theorema yang dipakai dalam statistik a untuk menghitung suatu peluang, "Bayes Optimal Classifier menghitung peluang dari satu kelas dari masing- masing kelompok atribut yang ada", dan menentukan kelas mana yang paling optimal.

\section{METODOLOGI PENELITIAN}

\subsection{Analisis Sentimen}

Analisis sentimen adalah deteksi sikap-sikap (attitudes) terhadap objek atau orang [2]. Dari miliaran data cuwitan di twitter, anda dapat melakukan analisis sentimen untuk menemukan berapa persentase 
Vol. 1, No. 3, September 2020 e-ISSN: 2775-2496

https://journal-computing.org/index.php/journal-cisa/index

sentimen positif dan berapa persentase sentimen negatif terhadap seseorang, perusahaan, institusi, kelompok, atau sebuah situasi tertentu.

\subsection{Metode Penelitian}

Dalam penelitian ini peneliti menggunakan metode deskriptif (Deskriptive Research). Metode deskriptif adalah metode yang berfungsi untuk mendeskripsikan atau menggambarkan terhadap objek yang diteliti melalui data atau sampel yang telah terkumpul tanpa bermaksud membuat kesimpulan yang berlaku umum atau generalisasi [3].

\subsection{Metode Pengumpulan Data}

Peneliti menggunakan metode crawling untuk mengumpulkan data. Crawling adalah suatu teknik yang digunakan untuk mengumpulkan informasi yang ada dalam web. Crawling berkerja secara otomatis, dimana informasi yang dikumpulkan berdasarkan atas kata kunci yang diberikan oleh pengguna. Alat yang digunakan untuk crawling disebut crawler. Crawler berbentuk program yang diprogram dengan algoritma tertentu sehingga dapat melakukan pemindaian ke halaman-halaman $w e b$, sesuai dengan alamat web ataupun kata kunci yang diberikan pengguna. Peneliti menggunakan Python untuk crawling data twitter ini.

\subsection{Metode Analisis}

Dalam penelitian ini, peneliti menggunakan metode Naive Bayes Classifier untuk menganalisis data yang telah diambil dari twitter. Nä̈ve Bayes adalah metode terbaru yang digunakan untuk mengklasifikasikan sekumpulan dokumen. "Algoritma ini memanfaatkan metode probabilitas dan statistik yang dikemukakan oleh ilmuwan Inggris Thomas Bayes, yaitu memprediksi probabilitas di masa depan berdasarkan pengalaman di masa sebelumnya" [4]. Keuntungan penggunaan metode Naive Bayes adalah bahwa metode ini hanya membutuhkan jumlah data pelatihan (Training Data) yang kecil untuk menentukan estimasi parameter yang diperlukan dalam proses pengklasifikasian.

\section{HASIL DAN PEMBAHASAN}

\subsection{Perangkat}

Adapun perangkat yang digunakan dalaam melakukan penelitian ini adalah sebagai berikut 
Vol. 1, No. 3, September 2020 e-ISSN: 2775-2496

https://journal-computing.org/index.php/journal-cisa/index

a. Perangkat keras (hardware) yang digunakan adalah 1 buah notebook denga spesiikasi processor Intel $(R)$ Celeron $(R)$ CPU N2840@2.16GHz, dengan RAM 2 GB dan HarDisk 500 GB

b. Perangkat lunak (Software) yang digunakan yaitu Operating System Microsoft Windows 8.1 sebagai sistem operasi, Microsoft Excel 2013, Microsoft Word 2013, dan Anaconda.

\subsection{Mengumpulkan Data Tweet}

Pengumpulan data dilakukan dengan teknik crawling, Tahap awal untuk melakukan proses pengambilan data dari Twitter, peneliti harus memiliki key number dan secret number dari API Key Twitter"'"Mendapatkan API Key Twitter peneliti harus mendaftarkan atau melakukan pengajuan terhadap pihak developer atau pengembang Twitter untuk mendapatkan API Key Twitter tersebut. Hasil proses crawling data, menggunakan API Key Twitter maka didapatkan data dengan jumlah 3.337 record Tweet, dengan ketentuan data latih sebesar $\mathbf{7 0 \%}$ dan data training sebesar 30\%"."

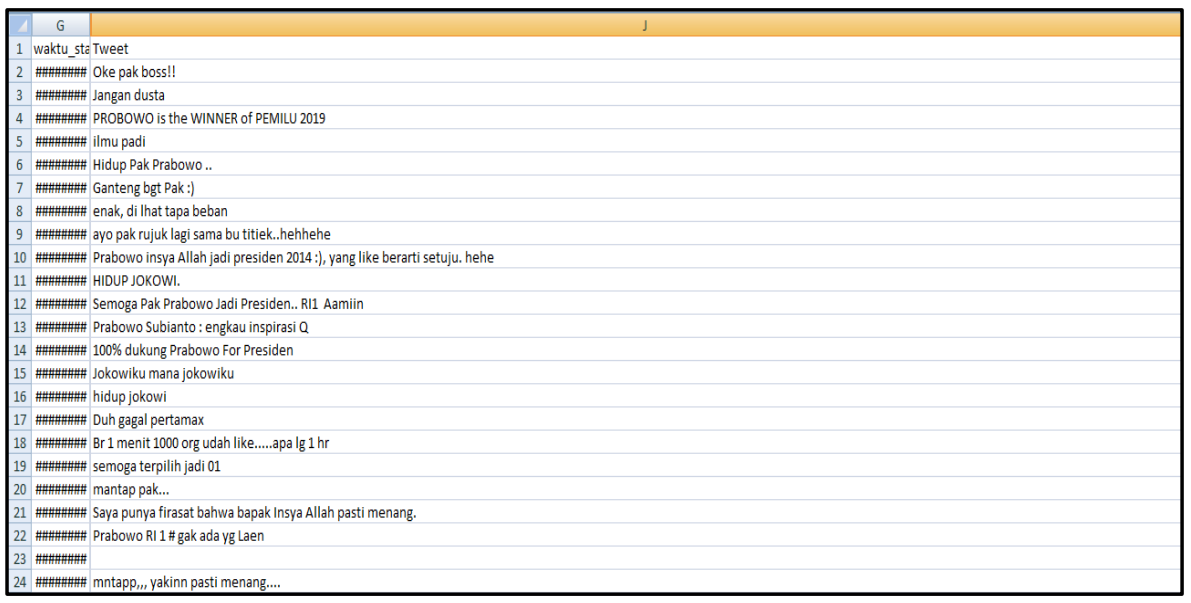

Gambar 1 Hasil Crawling

Hasil dari proses crawling data di atas kemudian akan dilakukan proces labeling data, proses ini dilakukan untuk menklasifikasikan data dari hasil tweet yang telah dicrawling sebelumnya. Pada proses labeling data ini, data dibedakan menjadi 2 kelas, yaitu kelas positif, dan kelas negatif. berikut merupakan contoh proces labeling data yang dapat dilihat di bawah ini. 
Vol. 1, No. 3, September 2020 e-ISSN: 2775-2496

https://journal-computing.org/index.php/journal-cisa/index

Tabel 1. Data Hasil labeling

\begin{tabular}{|c|c|c|}
\hline Tweet & Pembersihan Text & Label \\
\hline $\begin{array}{l}\text { b'RT @hd_hijau : jokowi yessssssss } \\
\text { \#pilpres\#jokowi\#prabowo } \\
\text { \#pemilu\#indonesia\#prabowosandi } \\
\text { \#pileg }\end{array}$ & Jokowi yes & 0 \\
\hline $\begin{array}{l}\text { B'Prabowo insya Allah jadi presiden } \\
2014 \text { :), yang like berarti setuju. Hehe } \\
\text { \#pilpres2014\#pemilu }\end{array}$ & $\begin{array}{l}\text { prabowo insya allah } \\
\text { jadi presiden } 2019 \text {, } \\
\text { yang like berarti } \\
\text { setuju. hehe }\end{array}$ & 0 \\
\hline $\begin{array}{l}\text { B'@detikcom : Tolak prabowo jd } \\
\text { presiden,masa lalunya yg penuh } \\
\text { dosa,sampai2 mantan mertuanya } \\
\text { bilang prabowo itu penghianat,jd para } \\
\text { pendukung prabowo ga usah banyak } \\
\text { omong lah } \\
\text { \#jokowi\#prabowo\#pilpres } \\
\text { \#jokowipresidenri }\end{array}$ & $\begin{array}{l}\text { tolak prabowo jd } \\
\text { presiden,masa } \\
\text { lalunya yg penuh } \\
\text { dosa,sampai mantan } \\
\text { mertuanya bilang } \\
\text { prabowo itu } \\
\text { penghianat,jd para } \\
\text { pendukung prabowo } \\
\text { ga usah banyak } \\
\text { omong lah }\end{array}$ & 1 \\
\hline $\begin{array}{l}\text { B'Moga Bapak Jokowi Menjadi } \\
\text { Presiden NKRI,And Tentunya Tegas, } \\
\text { Ramah, Dan Bertanggung jawab, } \\
\text { :)\#pilpres\#jokowi }\end{array}$ & $\begin{array}{l}\text { moga bapak jokowi } \\
\text { menjadi presiden } \\
\text { nkri, tentunya tegas, } \\
\text { ramah, dan } \\
\text { bertanggung jawab } \\
\end{array}$ & 0 \\
\hline $\begin{array}{l}\text { b'@detikcom Kampret Sesumbar. } \\
\text { HIDUP JOKOWI } \\
\text { kampret\n\#JokowiPresidenRI' }\end{array}$ & $\begin{array}{l}\text { kampret sesumbar, } \\
\text { pembunuh mau jadi } \\
\text { presiden. hidup } \\
\text { jokowi }\end{array}$ & 1 \\
\hline
\end{tabular}

Dalam kasus ini kelas negatif berlabelkan 1 menyatakan bahwa tweet tersebut mengandung unsur hatespeech atau kata-kata yang mengandung ujaran kebencian, sedangkan kelas positif berlabelkan 0 adlah kat-kata yang netral yang tidak mengandung unsur ujaran kebencian di dalamnya.

\subsection{Preprocesing Data}

Preprocesing merupakan proses untuk menghilangkan kata-kata yang tidak diperlukan dalam analisis data ataupun kata-kata yang tidak memiliki arti. 
Vol. 1, No. 3, September 2020 e-ISSN: 2775-2496

https://journal-computing.org/index.php/journal-cisa/index

\section{a. Cleaning}

Cleaning merupakan proses untuk menghapus tanda baca, simbol, huruf kapital maupun bilangan angka yang muncul pada tweet pengguna Twitter, yang menyebabkan data tersebut menjadi data yang kurang efektif untuk dilakukan analisa. Penerapan proses cleanning dapat dilihat pada Tabel 2 berikut ini

Tabel 2. Data Hasil Cleaning.

\begin{tabular}{|c|c|}
\hline Tweet Sebelum Cleaning & Tweet Sesudah Cleaning \\
\hline $\begin{array}{l}\text { @hd_hijau : jokowi yessssssss } \\
\text { ces\#jokowi\#prabowo } \\
\text { ilu\#indonesia\#prabowosandi }\end{array}$ & jokowi yes \\
\hline $\begin{array}{l}\text { owo insya Allah jadi presiden } 2014 \\
\text { g like brarti setuju. Hehe } \\
\text { es2014\#pemilu }\end{array}$ & $\begin{array}{l}\text { prabowo insya allah jadi } \\
\text { presiden 2019, yang like } \\
\text { brarti setuju. hehe }\end{array}$ \\
\hline $\begin{array}{l}\text { B'@detikcom : }^{\prime} \text { Tolak prabowo jd } \\
\text { presiden,masa lalunya yg penuh } \\
\text { dosa,sampai2 mantan mertuanya bilang } \\
\text { prabowo itu penghianat,jd para } \\
\text { pendukung prabowo ga usah banyak } \\
\text { omong lah } \\
\text { \#jokowi\#prabowo\#pilpres } \\
\text { \#jokowipresidenri }\end{array}$ & $\begin{array}{l}\text { tolak prabowo jd } \\
\text { presiden,masa lalunya yg } \\
\text { penuh dosa,sampai mantan } \\
\text { mertuanya bilang prabowo } \\
\text { itu penghianat,jd para } \\
\text { pendukung prabowo ga usah } \\
\text { banyak omong lah }\end{array}$ \\
\hline $\begin{array}{l}\text { B'Moga Bapak Jokowi Menjadi Presiden } \\
\text { NKRI,And Tentunya Tegas, Ramah, Dan } \\
\text { Bertanggung jawab, :) } \\
\text { \#pilpres\#jokowi }\end{array}$ & $\begin{array}{l}\text { moga bapak jokowi menjadi } \\
\text { presiden nkri, } \\
\text { tegas, ramtunya } \\
\text { bertanggung jawab }\end{array}$ \\
\hline $\begin{array}{l}\text { b'@detikcom Kampret Sesumbar. HIDUP } \\
\text { JOKOWI } \\
\text { kampret } \backslash \text { n\#JokowiPresidenRI' }\end{array}$ & \begin{tabular}{ll} 
kampret & \multicolumn{2}{r}{ sesumbar, } \\
pembunuh mau jadi & \\
presiden. hidup jokowi
\end{tabular} \\
\hline
\end{tabular}

b. Remove Stop word

Remove Stopword merupakan proses untuk menghapus kata - kata yang tidak memiliki makna ataupun arti seperti kata dan, atau, dengan, dan lain-lain. Penerapan proses Remove Stopword dapat dilihat pada Tabel 3 berikut ini.

Tabel 3. Data Hasil Remove Stop word

Teweet Se belum Remove Stop Tweet Sesudah Remove Stopword 
Vol. 1, No. 3, September 2020 e-ISSN: 2775-2496

https://journal-computing.org/index.php/journal-cisa/index

word

\begin{tabular}{|c|c|}
\hline jokowi yes & jokowi yes \\
\hline $\begin{array}{l}\text { prabowo insya allah jadi presiden } \\
2019 \text {, yang like brarti setuju. hehe }\end{array}$ & $\begin{array}{l}\text { prabowo insya allah presiden } 2019 \text {, } \\
\text { brarti setuju. }\end{array}$ \\
\hline $\begin{array}{l}\text { tolak prabowo jd presiden,masa } \\
\text { lalunya yg penuh dosa,sampai } \\
\text { mantan mertuanya bilang } \\
\text { prabowo itu penghianat,jd para } \\
\text { pendukung prabowo ga usah } \\
\text { banyak omong lah }\end{array}$ & $\begin{array}{l}\text { tolak prabowo presiden, masa } \\
\text { penuh dosa,sampai mantan } \\
\text { mertuanya bilang prabowo } \\
\text { penghianat, para pendukung } \\
\text { prabowo ga usah banyak omong }\end{array}$ \\
\hline $\begin{array}{l}\text { moga bapak jokowi menjadi } \\
\text { presiden nkri, tentunya tegas, } \\
\text { ramah, dan bertanggung jawab }\end{array}$ & $\begin{array}{l}\text { bapak jokowi presiden nkri, tegas, } \\
\text { ramah, bertanggung jawab }\end{array}$ \\
\hline $\begin{array}{l}\text { kampret sesumbar, pembunuh } \\
\text { mau jadi presiden. hidup jokowi }\end{array}$ & $\begin{array}{l}\text { kampret } \quad \text { sesumbar, } \\
\text { presiden. hidup jokowi }\end{array}$ \\
\hline
\end{tabular}

\section{c. Tokenization}

Tokenization merupakan proses untuk memisahkan kalimat kedalam bagian-bagian kecil yang disebut token. Suatu token bisa diannggap menjadi satu bentuk kata, frasa, dan atau suatu element yang mengandung arti. Proses tokenization dapat dilihat pada Tabel 4 berikut ini.

Tabel 4. Data Hasil Tokenization

\begin{tabular}{|c|c|}
\hline Tweet Sebelum Tokenization & Tweet Sesudah Tokenization \\
\hline jokowi yes & ['jokowi', 'yes'] \\
\hline $\begin{array}{l}\text { prabowo insya allah presiden } \\
\text { 2019, like berarti setuju. }\end{array}$ & $\begin{array}{l}\text { ['prabowo', } \\
\text { 'presiden', '2019', 'berarti', 'setuju']. }\end{array}$ \\
\hline $\begin{array}{l}\text { tolak prabowo presiden, masa } \\
\text { penuh dosa,sampai mantan } \\
\text { mertuanya bilang prabowo } \\
\text { penghianat, para pendukung } \\
\text { prabowo ga usah banyak omong }\end{array}$ & $\begin{array}{l}\text { ['tolak', 'prabowo', 'presiden', 'mas', 'penuh', 'dosa', 'sampai', } \\
\text { 'masa', 'mantan', 'mertuanya', 'bilang', ' } \\
\text { 'prabowo', 'penghianat', 'para', } \\
\text { 'pendukung, ' 'prabowo', 'banyak', } \\
\text { 'omong'] }\end{array}$ \\
\hline $\begin{array}{l}\text { bapak jokowi presiden nkri, tegas, } \\
\text { ramah, bertanggung jawab }\end{array}$ & $\begin{array}{l}\text { ['bapak', 'jokowi', 'presiden', 'nkri', } \\
\text { 'tegas', 'ramah', 'bertanggung', } \\
\text { 'jawab'] }\end{array}$ \\
\hline $\begin{array}{l}\text { kampret sesumbar, pembunuh } \\
\text { presiden. hidup jokowi }\end{array}$ & $\begin{array}{l}\text { ['kampret', 'sesumbar', 'pembunu } \\
\text { 'presiden', 'hidup', 'jokowi'] }\end{array}$ \\
\hline
\end{tabular}




\section{d. Stemming}

Stemming merupakan prooses untuk meruubah suatu kata kedalaam bentuk dasar dari kata tersebut dengan menghapus imbuhan katanya baik di depan ataupun di belakang kata. Proses pada tahap stemming dapat dilihat pada Tabel 5 di bawah ini.

Tabgel 5. Tabel Hasil Stemming

\begin{tabular}{|c|c|}
\hline Tweet Sebelum Stemming & Tweet Sesudah Stemming \\
\hline ['Jokowi', 'yes'] & jokowi yes \\
\hline $\begin{array}{l}\text { ['prabowo', 'insya', 'allah', 'presiden', } \\
\text { '2019', 'like', 'berarti', 'setuju']. }\end{array}$ & $\begin{array}{l}\text { prabowo insya allah presiden } \\
\text { 2019 berarti setuju. }\end{array}$ \\
\hline $\begin{array}{l}\text { ['tolak', 'prabowo', 'presiden', } \\
\text { 'masa', 'penuh', 'dosa', 'sampai', } \\
\text { 'mantan', 'mertuanya', 'bilang', } \\
\text { 'prabowo', 'penghianat', 'para', } \\
\text { 'pendukung', 'prabowo', 'banyak', } \\
\text { 'omong'] }\end{array}$ & $\begin{array}{l}\text { tolak prabowo presiden masa } \\
\text { penuh dosa sampai mantan } \\
\text { mertua bilang prabowo khianat } \\
\text { para dukung prabowo banyak } \\
\text { omong }\end{array}$ \\
\hline $\begin{array}{l}\text { ['bapak', 'jokowi', 'presiden', 'nkri', } \\
\text { 'tegas', } \\
\text { 'jawab'] }\end{array}$ & $\begin{array}{l}\text { bapak jokowi presiden nkri tegas } \\
\text { ramah tanggung jawab }\end{array}$ \\
\hline $\begin{array}{l}\text { ['kampret', 'sesumbar', 'pembunuh', } \\
\text { 'presiden', 'hidup', 'jokowi'] }\end{array}$ & $\begin{array}{l}\text { kampret } \begin{array}{r}\text { sesumbar } \\
\text { presiden hidup jokowi }\end{array}\end{array}$ \\
\hline
\end{tabular}

\subsection{Ekstrak si Fitur}

Pada proses ekstraksi fitur, proses pertama yang dilakukan sistem setelah tokenization adalah merubah dataset menjadi suatu representasi vecktor.

(DTweet1) "Jokowi Yes"

(DTweet2) "Prabowo Insya Allah Presiden 2019 Berarti Setuju"

(DTweet3) "Kampret Sesumbar Bunuh Presiden Hidup Jokowi"

Setelah sistem melaukukan proses preprocessing, terdapat 41 kata baku dari 3 kalimat di atas yaitu "Presiden"," Setuju"," Hidup", dhan " Bunuh".

Setelah tahapan di ahas dari setiap dokumen ditampilkan mejadi sebuah veictor dengan elemen, ketika kata tersebit terdapat di dalam dokumen maka diberikan nilai 1 , jika tidak ada maka diberikan nilai 0 . 
Vol. 1, No. 3, September 2020 e-ISSN: 2775-2496

https://journal-computing.org/index.php/journal-cisa/index

Tabel 6. Pembuatan Word Vector

\begin{tabular}{lllll}
\hline & Presiden & Setuju & Hidup & Bunuh \\
\hline DTweet 1 & 1 & 1 & 0 & 0 \\
DTweet2 & 0 & 0 & 2 & 1 \\
DTweet 3 & 1 & 0 & 0 & 1 \\
\hline
\end{tabular}

Dokumen yang telah dirubah menjadi word vecrtor maka selanjutnya akan dilakukan perhitungan menggunakan rumus TF-IDF, menggunakan rumus ini maka akan menghasilkan word vecteor yang memiliki nilai sudah terbobot. Berikut merupakan proses perhitungan TF-IDF

Tabel 7. Perhitungan TF (Term Frequency)

\begin{tabular}{llll}
\hline & DTweet 1 & DTweet 2 & DTweet 3 \\
\hline Presiden & 1 & 0 & 1 \\
Setuju & 1 & 0 & 0 \\
Hidup & 0 & 2 & 0 \\
Bunuh & 0 & 1 & 1 \\
\hline
\end{tabular}

Setelah proses perhitungan menentukan bobot $T F$ selesai, maka dilanjutkan dengan proses menentukan $D F$ (Document Frequuency) dengan cara menghitung banyaknya term $(t)$ yang muncul dalam suatu dokumen. Berikut adalah hasil dari proses tersebut.

Table 8. Perhitungan DF (Document Frequuency)

\begin{tabular}{ll}
\hline T (Term) & DF (Documeent Frequency) \\
\hline Presiden & 2 \\
Setuju & 1 \\
Hidup & 2 \\
Bunuh & 2 \\
\hline
\end{tabular}

Selanjutnya dilakukan perhitungan nilai IDF (Inverse Docuument Frequency) yaitu dengan cara melakukan perhitungan terhadap nilai dari log hasil D yang merupakan jumlah document. Contoh dalam kasus ini terdapat 3 tweet, dari 3 tweet tersebut dibagi dengan hasil nilai $D F$. Berikut adalah hasil dari perhitungan $I D F$

Tabel 9. Proses IDF (Inverse Document Frequency)

\begin{tabular}{llll}
\hline $\mathrm{T}$ & DF (Document & IDF (Inverse \\
(Term) & Frequency) & D/DF & $\begin{array}{l}\text { Document } \\
\text { Frequency) }\end{array}$
\end{tabular}


Vol. 1, No. 3, September 2020 e-ISSN: 2775-2496

https://journal-computing.org/index.php/journal-cisa/index

\begin{tabular}{llll} 
Presiden & 2 & 1.5 & $\log 1,5=0,176$ \\
Setuju & 1 & 3 & $\log 3=0,477$ \\
Hidup & 2 & 1.5 & $\log 1,5=0,176$ \\
Bunuh & 2 & 1.5 & $\log 1,5=0,176$ \\
\hline
\end{tabular}

Setelah mendapatkan nilai $I D F$, maka selanjutnya dilakukan perhitungan TF-IDF seperti dibawah ini

Tabel 10. Proses Perhitungan TF-IDF

\begin{tabular}{|c|c|c|c|c|c|c|c|c|c|c|}
\hline \multirow[t]{2}{*}{ Q } & \multicolumn{3}{|c|}{$\mathrm{TF}$} & \multirow[b]{2}{*}{ DF } & \multirow[b]{2}{*}{$\mathrm{D} / \mathrm{DF}$} & \multirow[b]{2}{*}{ IDF } & \multirow[b]{2}{*}{$\mathrm{IDF}+1$} & \multirow[b]{2}{*}{ Dtweet1 } & \multirow[b]{2}{*}{ Dtweet2 } & \multirow[b]{2}{*}{ Dtweet3 } \\
\hline & Dtweet1 & Dtweet2 & Dtweet3 & & & & & & & \\
\hline Presiden & 1 & 0 & 1 & 2 & 1.5 & 0.477 & 1.176 & 1.176 & 0 & 1.176 \\
\hline Setuju & 1 & 0 & 0 & 1 & 3 & 0.176 & 1.477 & 1.477 & 0 & 0 \\
\hline Hidup & 0 & 2 & 0 & 2 & 1.5 & & 1.176 & 0 & 2.35 & 0 \\
\hline Bunuh & 0 & 1 & 1 & 2 & 1.5 & 0.176 & 1.176 & $\begin{array}{l}0 \\
2.653\end{array}$ & $\begin{array}{l}1.176 \\
3.528\end{array}$ & $\begin{array}{l}1.176 \\
2.352\end{array}$ \\
\hline
\end{tabular}

Hasil yang didapat dari word vector yang telah dilakukan pembobotan dapat dilihat pda Tabel 11 di bawah ini.

Tabel 11. Word Vector yang Sudah Dibobotkan

\begin{tabular}{lllll}
\hline & Presiden & Setuju & Hidup & Bunuh \\
\hline DTweet 1 & 1.176 & 1.477 & 0 & 0 \\
DTweet 2 & 0 & 0 & 2.352 & 1.176 \\
DTweet 3 & 1.176 & 0 & 0 & 1.176 \\
\hline
\end{tabular}

\subsection{Klasifikasi Naive Bayes Pada Python}

Pada proses ekstraksi fitur dan proses pengklasifikasian Nä̈ve Bayes yang nantinya akan di kompres menjadi satu kelas pipeline vectorizer kemudian transfomer kemudian classifier. Untuk melakukan proses klasifikasi tersebut dijalankan menggunakan bantuuan library pada bahaasa pemrograman Python yaitu library scikit-learn untuk proses pengklasifikasian, selain itu digunakan juga library numpy dan library pandas untuk pembacaan data. Untuk library scikit-learn disini yang digunakan yaitu Pipeline, Naive Bay es, CountVectorizer, Multinomia INB, Tfidf Transformer, f1 Score, dan Confusion Matrix.

Tahap awal yang perlu dilakukan untuk proses ekstraksi fitur dan klasifikasi yaitu melakukan proces pengistalan library yang dibutuhkan. Selanjutnya setelah semua library terinstall, maka dilanjutkan dengan pendeklarasian semua library yang akan digunakan di dalam program 
Vol. 1, No. 3, September 2020 e-ISSN: 2775-2496

https://journal-computing.org/index.php/journal-cisa/index

python. Berikut adalah kode program untuk deklarasi library di python yang ditunjukkan pada Gambar 2 di bawah ini.

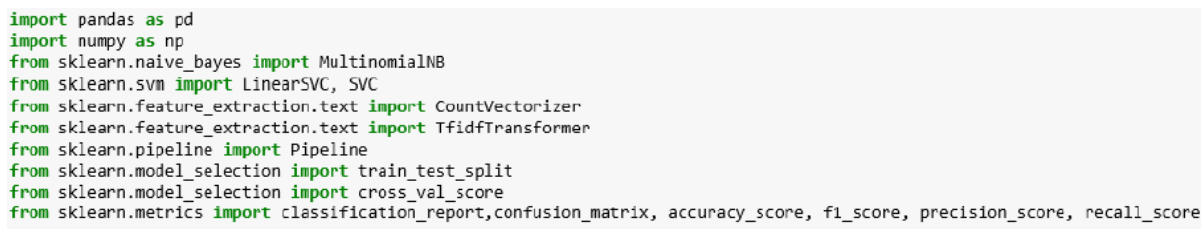

Gambar 2. Fungsi pendeklarasi an libraary

Setelah library selesai dideklarasikan maka dilanjutkan dengan proses pengambilan dataset yang akan digunakan sebagai data training yang dilakukan menggunakan library panndas. Berikut adalah kode program dapat dilihat pada Gambar 3 di bawah ini.

data $=$ pd.read_excel('analissentimenpilpres2019.CSV'), encoding='Latin-1') len(data)

\section{Gambar 3. Fungsi Memang gil Data $S$ e $t$}

Selanjutnya yaitu proses dalam membuat class pipeline yang didalamnya terdapat 3 tahapan yaitu mengubah dataset hasil dari crawling data Twiitter menjadi representasi vector yaitu mengubah huruf menjadi angka dengan bantuan library Count Vectorizer serta dengan pembobotan menggunakan word vector didalam library Tfidf Transformer, kemudian dilakukan pengklasifikasian dengan menggunakan bantuan library Multinominal NaiveBayes. Berikut adalah proses dari pengimplementasian ketiga proses pembuatan class pipeline dapat dilihat pada Gambar 4 di bawah ini.

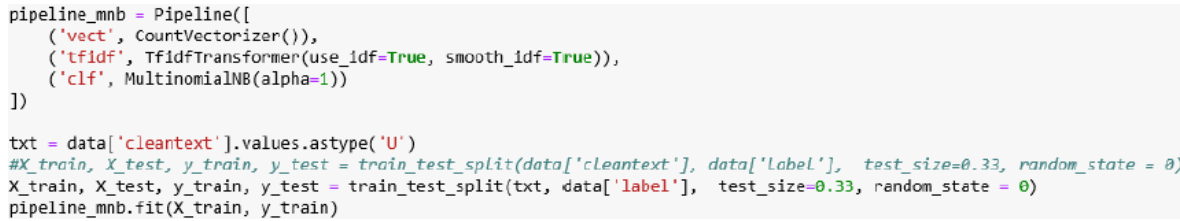

Gambar 4. Prosses Pengimplementasian Class Pipiline 
Vol. 1, No. 3, September 2020 e-ISSN: 2775-2496

https://journal-computing.org/index.php/journal-cisa/index

\subsection{Uji Model}

Peneliti melakukan uji model supaya dapat mengetahui tingkat dari performa Algoritma Naive Bayess. Nantinya hasil dari kasifikasi akan ditampilkan kedalam bentuk coun fusion matrix". Tabel yang ditampilkan dalam con fusion matrix tersebut terdiri dari class predicted dan juga class actual. Berikut adalah Model con fusion matrix seperti terlihat pada Ta bel 12 dibawah ini.

Tabel 12. Model Confusion Matrix

\begin{tabular}{llll}
\hline & & Pre dict Class & \\
\cline { 2 - 4 } & & C lass A & C lass B \\
\hline \multirow{2}{*}{ Actual Class } & Positif & TP & FP \\
\cline { 2 - 4 } & Negatif & FN & TN \\
\hline
\end{tabular}

Untuk mendapatkan nilai dari akurasi model diperoleh dengan hasil perhitungan banyaknya data dari hasil klarifikasi dibagi dengan total data, berikut adalah rumus untuk mencari akurasi.

$$
\text { Akurasi }=\frac{T P+T N}{T P+F P+T N+F N}
$$

Pada saat proses pengujian model dilakukan, maka hasilnya adalah nilai akurasi dan confusion matrix $2 \times 2$ sebesar $7.1 .0 \%$ yang proses perhitungannya didasarkan pada jumlah nilai dari diagonal con fusion matrix dibagi dengan keseluruhan jumlah data. Karena menyangkut dari jumlah data yang ada di setiap kelas data training tidak seimbang, maka besarnya dari nilai akurasi tidak menjandi hal yang paling penting.

\subsection{Evaluasi Model}

Proses dari evaluiasi model di lakukan setelah selesai melakukan uji model. Evaluasi model berfungsi untuk mengetahui atau menghitung performasi dari metode yang digunakan. Pada proses ini akan menghasilkan confusion matrix dengan ukuran $2 \times 2$.

Tabel 13. Hasil Confusion Matrix

\begin{tabular}{llll}
\hline & & \multicolumn{2}{c}{ Predict Class } \\
\cline { 3 - 4 } & & Positif & Negatif \\
\hline \multirow{2}{*}{ Actual Class } & Positif & 558 & 105 \\
\cline { 2 - 4 } & Negatif & 261 & 334 \\
\hline
\end{tabular}


Vol. 1, No. 3, September 2020 e-ISSN: 2775-2496

https://journal-computing.org/index.php/journal-cisa/index

Seperti yang terlihat pada Table 13 diatas, matriks yang ber ukuran $2 \times 2$ disetiap kolomnya mewakili nilai dari setiap dari kelas yaitu kelas positif, dan juga kelas negatif. Nilai presisi pada keseluruhan sistem adalah sebesar 0.704 sementara itu untuk nilai recall keseluruhan sistem sebesar 0.615 dan selanjutnya untuk nilai $f$-1 Score untuk pengevaluasian yang dihitung dengan mengombinasikan nilai dari precicion recall yaitu didapatkan nilai sebesar 0.65.6.

Dengan diketahuinya nilai kinerja dari recall, precicion, dan juga $f$-1 Score dikeseluruhan sistem, maka peneliti dapat mengetahui dari kemampuan sistem tersebut untuk mencari kebenaran atau ketepatan dari setiap informassi yang diminta oleh pengguna dengan hasil dari jawaban yang dikeluarkan oleh sistem dengan tingkat keberhasilan sistem untuk menentukan kembali informasi yang dibeikan dengan accuracy nilai sebesar $\mathbf{7 1} \%$.

Setelah semua proses diatas selesai dilakukan, untuk performa dari metode pengklasifikasian dari seitiap kelas bisa di ketahui dengan recall, precision, dan juga $f$-1 Score disetiap kelasnya. Hasil dari recall, precision, dan juga $f$-1 Score memiliki penilaian sebesar 0 sampai 1 . Semakin tinggi dari nilai yang dihasilkan maka itu berarti semakin baik sistem bekerja, dalam arti semakin nilai mendekati angka 1 maka itu artinya sistem semakin baik. Untuk hasil yang didapat dari proses pengevaluasian model dapat dilihat pada Gambar 5 di bawah ini.

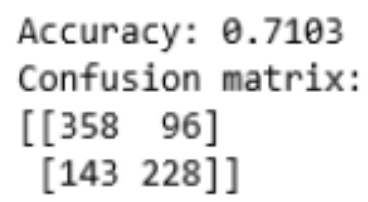

precision recall f1-score support

$\begin{array}{lllll}0 & 0.71 & 0.79 & 0.75 & 454 \\ 1 & 0.70 & 0.61 & 0.66 & 371\end{array}$

$\begin{array}{lllll}\text { avg / total } & 0.71 & 0.71 & 0.71 & 825\end{array}$

Gambar 5. Hasil dari Proces Pengevaluasian Model

Hasil yang didapat dari nilai recall, precision, dan juga $f$-1 Score di setiap kelas bisa dilihat dari Tabel 14 berikut ini. 
Vol. 1, No. 3, September 2020 e-ISSN: 2775-2496

https://journal-computing.org/index.php/journal-cisa/index

Tabel 14. Hasil dari Nilai Recall, Precision, dan F-1 Score

\begin{tabular}{llll}
\hline Klasifikasi & Precision & Recall & f-1 Score \\
\hline Positif & 0.71 & 0.79 & 0.75 \\
Negatif & 0.71 & 0.61 & 0.66 \\
\hline
\end{tabular}

Dari hasil evaluasi model pada Tabel 14 dapat diketahui nilai precision dan recall dari setiap kelas dapat dilihat tingkat kemempuan pemrosesan sistem dalam mencari tingkat ketepatan antara informasi yang diinginkan oleh pengguna sebagai kelas positif adalah "71\%", dan untuk kelas negatif adalah "70\%". Tingkat keberhasilan dari pemrosesan sistem dalm memperoleh kembali informasi kelas positif adalah "79\%", untuk kelas negatif adalah "61\%". Berdasarkan hasil Tweet dengan data 3.337, dengan ketentuan data latih sebesar $70 \%$ dan data training sebesar $30 \%$. Dengan hasil yang didapat peneliti menyimpulkan dalam analisis sentiment pemilihan presiden 2019 nilai positif lebih tinggi dengan selisih sebesar $18 \%$ dengan tingkat akurasi sangat tinggi yaitu sebesar 71\%. Dengan hasil nilai tersebut dapat diartikan bahwa keberhasilan sistem untuk menentukan kembali sebuah informasi yang mengandung nilai positif dan negatif dalam suatu dokumen sangat tinggi.

\section{KESIMPULAN}

Berdasarkan penelitian yang dilakukan dan hasil pembahasan yang diuraikan di atas, maka dapat ditarik kesimpulan sebagai berikut:

1. Metode Naive Bayes bisa digunakan untuk mengklasifikasikan data berupa teks, terutama teks yang berasal dari tweet Twitter.

2. Jumlah kata dalam setiap kelas training sangat mempengaruhi hasil dari klasifikasi pada data testing, oleh karena itu keseimbangan dari data perlu dijaga.

3. Kosakata tidak baku dapat mempengaruhi hasil klasifikasi terhadap suatu kelas testing apabila suatu kelas training memiliki data dari jumlah kata tidak baku lebih banyak dibanding kelas training yang lain.

\section{DAFTAR PUSTAKA}

[1] Odewole. (2017) The Role of Librarian in Using Social Media Tools to Promote the Research Output of HIS/HER Clienteles. Journal of Education and Practice, 8 (27), 109-113.

[2] Beineke, P., Hastie, T., Manning, C., \& Vaithyanathan, S. 2004. Exprloring Sentiment Summarization. In Y. Qu, J. Shanahan, \& J. 
Wiebe (eds) Proceedings of then \{AAAI Spring Symposium on Exploring Attitude and Affect in Text: Theories and Applications, AAAI Press.

[3] Sugiono (2016). Metode Penelitian Kuantitatif, Kualitatif, dan R\&D. Alfabeta. Bandung.

[4] Dr. Ghayda A. Al-Talib1, Hind S. Hassan, A . (2013). Study on Analysis of SMS Classification Using TF-IDF Weighting 